\title{
耐糖能異常者における小粒子径低比重リポ蛋白と血中脂質, 肥満およびインスリン感受性との関係*
}

住吉良太吕末廣正苂橋本浩 三** 大野文 俊**

\section{I. はじめに}

近年, インスリン抵抗性, 而糖能異常に血中脂質異常, 高血圧あるいは肥満の合併する病態が存在し，これに動 脈硬化性疾患を伴いやすいことが報告されている ${ }^{1 \sim 3)}$. これらの一群を Reaven は Syndrome X ${ }^{1)}$, DeFronzo は インスリン抵抗性症候群 ${ }^{3)}$ という名称で表現している. 一方, 血中の低比重リポ蛋白 (LDL) は heterogeneous であるが4 6)，われわれは密度勾配電気泳動法を用いて， インスリン非依存型糖尿病 (NIDDM) 患者では小粒子径 LDL (small LDL) の頻度が高いことを示し，さらに， small LDL をもつ群は高トリグリセライド (TG) 血症, 低 HDL コレステロール (HDL-C) 血症, 肥満傾向を伴 っていることを報告した7).

これら small LDL 群が上記インスリン抵抗性症候群 と重なることが考えられるため, 今回, 耐糖能異常者の うち impaired glucose tolerance (IGT) および食事療法 のみの NIDDM 患者に打いて LDL 亜分画と, 血漿脂 質, 肥満, 未梢インスリン感受性, 血圧等との関係につ いて検討した.

\section{II. 対象と方法}

\section{1. 対 象}

一般の健常成人の LDL 亜分画は, 検診センターを受 診し, IGT, NIDDM, 虚血性心疾患, 脳血管障害, 肝 膵および腎障害のない 221 例 (男/女; 111/110 例, 平均 年齢 46.5 $\pm 11.0 / 45.7 \pm 9.8)$ で検討した.

\footnotetext{
* 1991 年 12 月 6 日, 日本動脈硬化学会平成 3 年度冬 季大会にて発表

** 高知医科大学第二内科学教室

原稿受取日：1992 年 7 月 23 日

採用決定日：1992 年 8 月 17 日
}

耐糖能異常者としては平成 2 年 8 月から 4 年 5 月まで に当科を受診した NIDDM および $75 \mathrm{~g}$ OGTT で IGT (WHO の基準) と診断されている患者のうちの男性35例, 女性 20 例の計 55 例である. NIDDM は SU 剤, インス リンの影響のない食事療法のみに限った 43 例 (男/女 ; 24/19) で, IGT は 12 例 (11/1) である.いずれもインス リン抗体は認めていない. 大血管障害の既往歴をもつも のは13例で, 虚血性心疾患のみ 5 例 (男/女; $3 / 2$ ), 脳血 管障害のみ 6 例 $(5 / 1)$, 両疾患を有するもの 2 例 $(1 / 1)$ で あった. 総コレステロール (TC) $220 \mathrm{mg} / \mathrm{d} l$ 以上, TG $150 \mathrm{mg} / \mathrm{d} l$ 以上の少なくともいずれかをみたす高脂血症 の合併は29例で, phenotype は IIa 型 3 例 (男/女; 1/2), IIb 型13 例 (6/7), IV 型 13 例 (11/2) である. 合併症によ るリポ蛋白への影響を避けるため, 血清クレアチニン $1.3 \mathrm{mg} / \mathrm{d} l$ 以上の腎症, および肝膵疾患を有するものは 除外した。また降圧剤服用者は 7 例 ( $\mathrm{Ca}$ 拮抗剤 6 例, $\mathrm{ACE}$ 阻害剤 1 例), 抗高脂血症剂服用者は 4 例 (HMG$\mathrm{CoA}$ 還元酵素阻害剤 2 例, パントテン酸 2 例) であり, クロフィブラート系服用者は LDL 粒子径に影響する ${ }^{8)}$ ことより除外した. 対照として上記健常者のなかから年 齢, 性および body mass index (BMI) がほぼ一致し, か つ著明な高脂血症 $(\mathrm{TC} \geqq 250 \mathrm{mg} / \mathrm{d} l, \mathrm{TG} \geqq 200 \mathrm{mg} / \mathrm{d} l)$ が ない55例を選んだ. Table 1 に耐糖能異常者と健常対照 者の内容を示した.

\section{2. 方 法}

1) LDL 粒子径測定

早朝空腹時に $0.1 \%$ EDTA 採血を行い血漿を得た. LDL 粒子径の測定は血漿を密度勾配電気泳動後, 脂肪 染色することにより求めた5).すなわち 2-16\% ポリアク リルアミドグラジェントゲル (PAA 2/16, Pharmacia) に 上記血漿 $10 \mu \mathrm{l}$ を添加し, $10^{\circ} \mathrm{C}$, 定電圧 $125 \mathrm{~V}$ で 24 時間 泳動した。泳動緩衝液はトリス $(0.09 \mathrm{M})$-ホウ酸 $(0.08$ 
M)-EDTA $(0.003 \mathrm{M})$ 緩衝液, pH 8.3 を用いた. 染色を $0.04 \%$ オイルレッド $\mathrm{O} / 60 \%$ エタノールで $37^{\circ} \mathrm{C}, 48$ 時 間, 脱色をエタノール/酢酸/水 $(24 / 9 / 67)$ で 1 時閒行 った後, 24時間蒸留水に浸した. 移動距離のマーカーは,

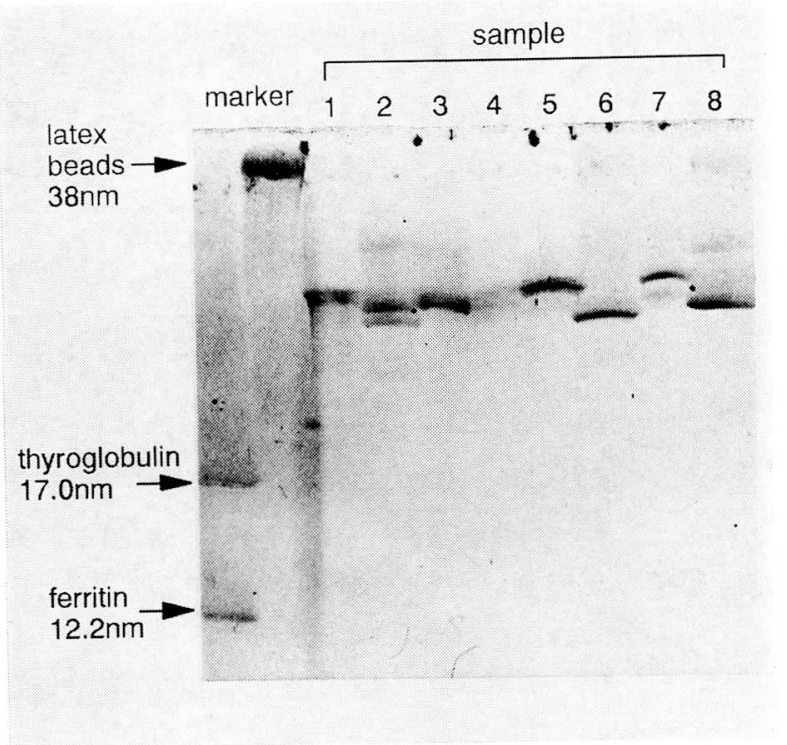

Fig. 1 Non-denaturing polyacrylamide gradient gel electrophoresis of whole plasma. Samples (Nos. 1 to 8 ) from the patients with glucose intolerance, and latex beads were stained by Oil Red $\mathrm{O}$, and thyroglobulin and apoferritin were stained by Coomassie Blue R-250. Because of heterogenity of LDL particle, one to three bands were revealed on the gel. The main peak size was regarded as the LDL particle size. Sample Nos. 6 and 8 show small LDL (peak LDL particle size $<25.7 \mathrm{~mm}$ ). Sample No. 2 shows normal LDL with small LDL. Sample Nos. 5 and 7 show LDL of larger particle size.
粒子径 $38.0 \mathrm{~nm}$ のラテックスビーズ (Dow Chemical), $17.0 \mathrm{~nm}$ のサイログロブリンおよび $12.2 \mathrm{~nm}$ のアポフェ リチン (Electrophoresis Calibration Kit, Pharmacia) を 用いた. ビーズはサンプルと同時に脂肪染色し, 蛋白質 のマーカーは $0.1 \%$ クマジーブルー R-250/50\% トリク ロロ酢酸を濾紙に湿し, マーカーの部位を10分覆うこと により染色した. LDL とビーズは吸光度 $500 \mathrm{~nm}$, 蛋白 質マーカーは $620 \mathrm{~nm}$ でデンシトグラフィーを行い, 移 動距離を求めた。これらの移動距離から Williams ら ${ }^{9)}$ の方法に従い 2 次多項式の標準曲線を求め, これより粒 子径を得た。なお, LDL 粒子は heterogeneous であるが, 泳動上の主ピークを LDLの粒子径とした. 泳動, 染色 後のゲルを Fig. 1 に示す. VLDL 分画は粒子サイズが 大きいため, ほとんどゲルに入らず, また, HDL 粒子 はすでに通過して本ゲル上ではみられない.

2) 肥満および脂肪分布

Waist to hip circumference ratio (WHR) は Larsson らの方法 ${ }^{10)}$ に従い, 空腹時に臍の高さの周囲径と腸骨 稜の周囲径より求めた.

Intraabdominal visceral fat to subcutaneous fat ratio $(\text { VSR })^{11,12)}$ は臍の高さの CT 画像を Image Analyzer Luzex III (Nikon) に取り込み, 皮下脂肪 (subcutaneous fat) と内臓脂肪 (visceral fat) の面積を測定し, 比を求め た.

3) euglycemic insulin clamp study

人工膵臓 (Biostator, Miles) を用い, DeFronzo らの方 法 ${ }^{13)}$ に従いインスリン $\left(40 \mathrm{mU} / \mathrm{min} / \mathrm{m}^{2}\right)$ を 2 時間持続 注入し,グルコース注入量が steady state になった時点 で30分間のグルコース注入量を算出し，インスリン感受 性の指標である $M$ 值 $(\mathrm{mg} / \mathrm{min} / \mathrm{kg})$ を求めた.

血漿中の $\mathrm{TC}, \mathrm{TG}$ は酵素法 (デタミナー TC5, TG, 協

Table 1 Clinical data of the normal controls and the patients with glucose intolerance

\begin{tabular}{|c|c|c|c|c|c|}
\hline & & \multicolumn{2}{|c|}{ Normal controls } & \multicolumn{2}{|c|}{ Patients } \\
\hline & & Male & Female & Male & Female \\
\hline Cases & & 35 & 20 & 35 & 20 \\
\hline Age & (yrs) & $49.7 \pm 11.6$ & $57.2 \pm 9.5$ & $49.6 \pm 11.6$ & $57.2 \pm 16.9$ \\
\hline BMI & & $24.6 \pm 2.1$ & $23.7 \pm 3.9$ & $24.9 \pm 3.3$ & $23.8 \pm 5.4$ \\
\hline NIDDM/IGT & (number) & $(-)$ & $(-)$ & $24 / 11$ & $19 / 1$ \\
\hline Total cholesterol & $(\mathrm{mg} / \mathrm{d} l)$ & $197 \pm 33$ & $206 \pm 21$ & $193 \pm 31$ & $207 \pm 48$ \\
\hline Triglyceride & $(\mathrm{mg} / \mathrm{d} l)$ & $110 \pm 39$ & $85 \pm 34$ & $166 \pm 98 *$ & $146 \pm 87^{*}$ \\
\hline HDL-C & $(\mathrm{mg} / \mathrm{d} l)$ & $41.9 \pm 9.7$ & $47.9 \pm 12.1$ & $49.0 \pm 9.6$ & $51.4 \pm 11.9$ \\
\hline FPG & $(\mathrm{mg} / \mathrm{d} l)$ & $89 \pm 7$ & $84 \pm 11$ & $132 \pm 47$ & $147 \pm 41$ \\
\hline $\mathrm{HbA}_{1 \mathrm{C}}$ & $(\%)$ & $\S$ & $\S$ & $7.38 \pm 1.94$ & $8.08 \pm 1.59$ \\
\hline systolic BP & $(\mathrm{mmHg})$ & $129 \pm 13$ & $124 \pm 23$ & $129 \pm 19$ & $117 \pm 13$ \\
\hline diastolic BP & $(\mathrm{mmHg})$ & $75 \pm 7$ & $68 \pm 12$ & $78 \pm 14$ & $71 \pm 8$ \\
\hline
\end{tabular}

IGT: impaired glucose tolerance (WHO), FPG: fasting plasma glucose, BP: blood pressure

$\S$ : not examined, $*: \mathrm{p}<0.01$ vs. normal contro! 

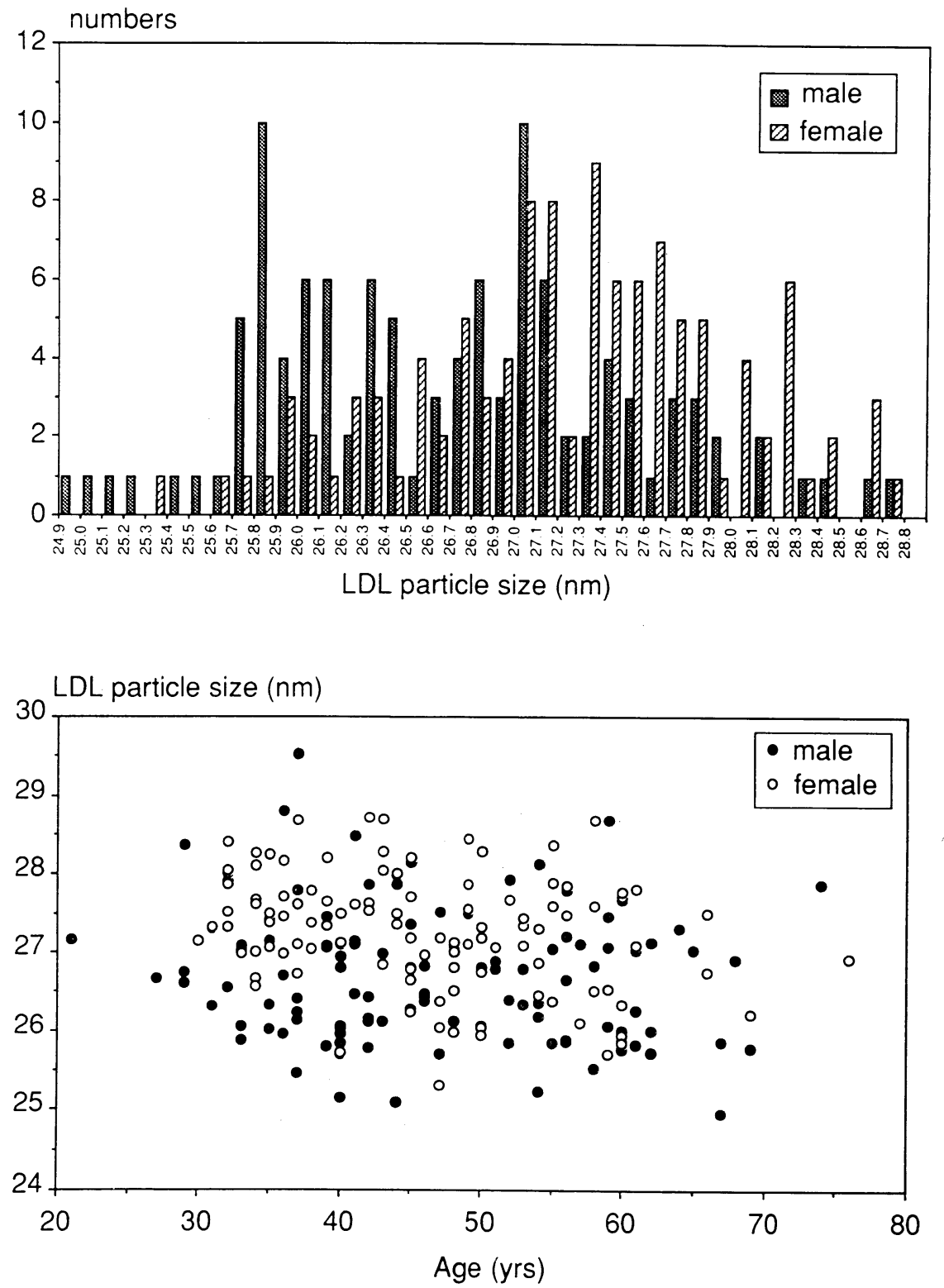

Fig. 2 Upper; Distribution of peak LDL particle size in normal population. Lower; Relation between peak LDL particle size and age.

和メデックス)，HDL-C はヘパリンマンガンーデキスト ラン硫酸沈澱法 ${ }^{14)}$ で測定した。血漿アポ B 濃度は一元 免疫拡散法（アポプレート，第一化学社）により測定し た. LDL コレステロール (LDL-C) は Friedewald の式 より算出した。血漿 immunoreactive insulin (IRI), 尿中 C-protein reactivity (CPR) は RIA (Ab ビーズインスリン 栄研, 栄研化学; CペプタイドRIA シオノギ, シオノギ で測定した.

成績の值はすべて mean \pm standard deviation (SD) で 示し，有意差検定は対応のないStudent の $\mathrm{t}$ 検定で，一 部 $\chi^{2}$ 検定で行った.

\section{III. 結 果}

\section{1. 健常者の LDL 粒子径の分布 (Fig. 2)}

今回の方法で健常者 221 例の LDL 粒子径の度数分布 をみると， $25.7 \mathrm{~nm}$ 以下のものは僅かであり，累積頻度 と粒子径との関係をみると $25.7 \mathrm{~nm}$ を境界に異なる直線 となった. また, LDL 分画の密度勾配電気泳動, 蛋白 染色法によると，その泳動パターンより pattern A， B に分けられるが，この境界 $(25.8 \mathrm{~nm})^{7,15)}$ ともほぼ一致 し, 今回は $25.7 \mathrm{~nm}$ 末満を small LDL，それ以上を normal LDL と定義した. 健常者の small LDL の頻度 


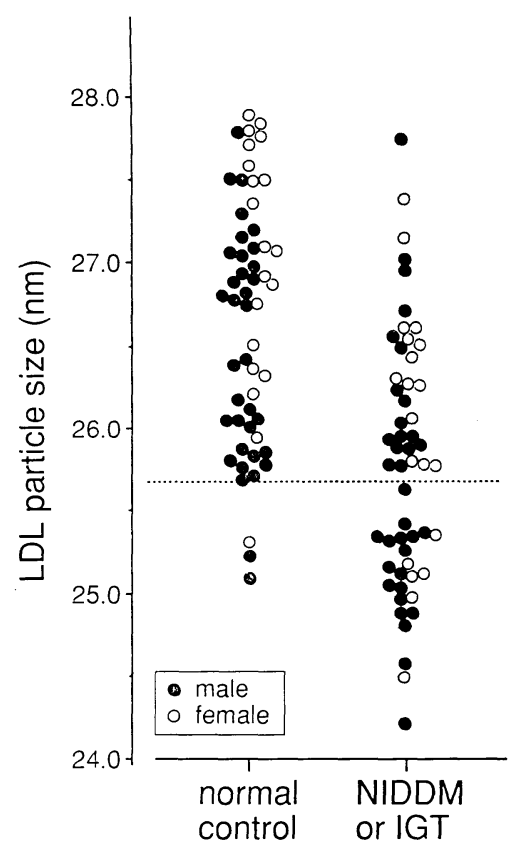

Fig. 3 Peak LDL particle sizes in 55 patients with glucose intolerance and 55 normal controls who were matched to the patients in sex, age and body mass index.
は 4.1\%(9/221 例) であり, 男性がより高頻度 (7 例) で あった．また，男性では 26.1 と $27.1 \mathrm{~nm}$ 前後を中心に 2 つの大きな分布がみられるのに対して, 女性では全体 に右に移動し， $27.3 \mathrm{~nm}$ 前後を中心に分布していた. LDL 粒子径と年齢との関係をみたが，35 歳以下には small LDL はみられないが，それ以外，年齢による明ら かな変動はみられなかった。

\section{2. 耐糖能異常者と健常対照者の LDL 粒子径の分布}

\section{(Fig. 3)}

耐糖能異常群の LDL 粒子径の平均は $25.81 \pm 0.79 \mathrm{~nm}$ で, 対照群は $26.66 \pm 0.75 \mathrm{~nm}$ であった。 それぞれ small LDL を示すものは耐糖能異常群では 43.6\% (24/55 例), 対照群では $5.5 \%$ (3/55 例) であり, 前者が有意に高頻度 であった ( $\chi^{2}$ 検定). 耐糖能異常群の中で男性の small LDL の頻度は $51.4 \%$ (18/35 例), 女性のそれは $30 \%$ (6/20例) であり，男性においてより高頻度であった。

耐糖能異常群のうち高脂血症合併例中, small LDL の 頻度は IIa 型で 3 例中 2 例, IIb 型で 13 例中 10 例，IV 型で13例中 9 例にみられ，正脂血症中では26例中 3 例の みであった. TG が $150 \mathrm{mg} / \mathrm{d} l$ 以下のものは29例で，こ のうち small LDL は 5 例 $(17.2 \%)$ であった。

Table 2 Clinical data of the small and normal LDL groups in the patients with glucose intolerance

\begin{tabular}{llccccc}
\hline & & \multicolumn{2}{c}{ Male } & & \multicolumn{2}{c}{ Female } \\
\cline { 3 - 4 } \cline { 6 - 6 } \cline { 6 - 6 } & & Normal LDL & Small LDL & & Normal LDL & Small LDL \\
\hline Age & $(\mathrm{yrs})$ & $51.1 \pm 11.6$ & $48.2 \pm 11.8$ & & $59.4 \pm 14.9$ & $51.8 \pm 21.4$ \\
History & $(\mathrm{yrs})$ & $5.3 \pm 8.9$ & $4.2 \pm 4.3$ & & $4.2 \pm 6.7$ & $3.5 \pm 3.2$ \\
FPG & $(\mathrm{mg} / \mathrm{d} l)$ & $124 \pm 48$ & $140 \pm 47$ & & $149 \pm 45$ & $143 \pm 32$ \\
HbA & $(\%)$ & $7.34 \pm 2.13$ & $7.42 \pm 1.82$ & & $8.19 \pm 1.78$ & $7.78 \pm 1.16$ \\
systolic BP & $(\mathrm{mmHg})$ & $132 \pm 21$ & $127 \pm 17$ & & $118 \pm 14$ & $115 \pm 14$ \\
diastolic BP & $(\mathrm{mmHg})$ & $79 \pm 14$ & $78 \pm 14$ & & $70 \pm 8$ & $74 \pm 9$ \\
\hline
\end{tabular}

FPG : fasting plasma glucose, BP: blood pressure

Table 3 Plasma levels of lipids, lipoproteins and apolipoproteins of the small and normal LDL groups in the patients with glucose intolerance

\begin{tabular}{|c|c|c|c|c|c|}
\hline & & \multicolumn{2}{|c|}{ Male } & \multicolumn{2}{|c|}{ Female } \\
\hline & & Normal LDL & Small LDL & Normal LDL & Small LDL \\
\hline Total cholesterol & $(\mathrm{mg} / \mathrm{d} l)$ & $179 \pm 25$ & $205 \pm 32 * *$ & $189 \pm 42$ & $250 \pm 32 * * *$ \\
\hline Triglyceride & $(\mathrm{mg} / \mathrm{d} l)$ & $112 \pm 50$ & $218 \pm 104 * * *$ & $110 \pm 66$ & $229 \pm 73 * * *$ \\
\hline HDL-C & $(\mathrm{mg} / \mathrm{d} l)$ & $52.4 \pm 10.7$ & $45.9 \pm 7.5^{*}$ & $54.3 \pm 12.2$ & $43.2 \pm 6.1$ \\
\hline LDL-C & $(\mathrm{mg} / \mathrm{d} l)$ & $143 \pm 29$ & $175 \pm 41 * *$ & $142 \pm 56$ & $212 \pm 20^{* *}$ \\
\hline LDL-C/HDL-C & & $2.82 \pm 0.77$ & $3.96 \pm 1.16 * * *$ & $2.81 \pm 1.54$ & $4.97 \pm 0.68^{* * *}$ \\
\hline Apo A-I & $(\mathrm{mg} / \mathrm{d} l)$ & $128 \pm 22$ & $123 \pm 24$ & $127 \pm 19$ & $128 \pm 18$ \\
\hline Apo B & $(\mathrm{mg} / \mathrm{d} l)$ & $87 \pm 12$ & $110 \pm 21^{* * *}$ & $93 \pm 26$ & $136 \pm 29 * * *$ \\
\hline Apo C-II & $(\mathrm{mg} / \mathrm{d} l)$ & $3.6 \pm 1.4$ & $7.1 \pm 4.1^{* *}$ & $4.6 \pm 3.6$ & $6.9 \pm 1.4$ \\
\hline Apo C-III & $(\mathrm{mg} / \mathrm{d} l)$ & $8.5 \pm 3.3$ & $17.8 \pm 12.4^{* *}$ & $10.0 \pm 5.3$ & $17.4 \pm 6.7$ \\
\hline
\end{tabular}


Table 4 Body mass index, waist to hip circumference ratio (WHR) and intraabdominal visceral fat to subcutaneous fat ratio (VSR) of the small and normal LDL groups in the patients with glucose intolerance

\begin{tabular}{lccccc}
\hline & \multicolumn{3}{c}{ Male } & & \multicolumn{2}{c}{ Female } \\
\cline { 2 - 3 } \cline { 5 - 6 } & Normal LDL & Small LDL & & Normal LDL & Small LDL \\
\hline BMI & $23.7 \pm 3.6$ & $26.1 \pm 2.5^{*}$ & & $22.4 \pm 5.4$ & $27.1 \pm 4.2$ \\
WHR & $0.931 \pm 0.043$ & $0.956 \pm 0.036$ & & $0.911 \pm 0.066$ & $1.004 \pm 0.041^{*}$ \\
VSR & $0.382 \pm 0.069$ & $0.549 \pm 0.135^{*}$ & & $0.220 \pm 0.067$ & $0.155 \pm 0.021$ \\
\hline
\end{tabular}

BMI: body mass index, WHR: waist to hip circumference ratio, VSR : intraabdominal visceral fat to subcutaneous fat ratio, *: $\mathrm{p}<0.05$

Table 5 Plasma fasting immunoreactive insulin level (F-IRI), urinary C-protein reactivity (U-CPR) and glucose disposable rate (M-value) of the small and normal LDL groups in the patients with glucose intolerance

\begin{tabular}{llccccc}
\hline & & \multicolumn{2}{c}{ Male } & & \multicolumn{2}{c}{ Female } \\
\cline { 3 - 4 } \cline { 5 - 6 } & & Normal LDL & Small LDL & Normal LDL & Small LDL \\
\hline F-IRI & $(\mu \mathrm{U} / \mathrm{m} l)$ & $7.14 \pm 3.22$ & $12.45 \pm 7.67^{* *}$ & & $9.17 \pm 4.84$ & $19.38 \pm 16.80^{*}$ \\
U-CPR & $(\mu \mathrm{g} / \mathrm{g} \cdot \mathrm{cr})$ & $91.3 \pm 39.7$ & $83.3 \pm 38.8$ & & $77.3 \pm 49.4$ & $55.0 \pm 42.3$ \\
M-value & $(\mathrm{mg} / \mathrm{min} / \mathrm{kg})$ & $6.05 \pm 1.56$ & $3.61 \pm 1.79$ & & $4.79 \pm 2.29$ & $2.34 \pm 0.04$ \\
\hline
\end{tabular}

F-IRI: fasting immunoreactive insulin, U-CPR: urinary C-protein reactivity, M-value were measured by insulin clamp study. ${ }^{*}: \mathrm{p}<0.05,{ }^{* *}: \mathrm{p}<0.02$

Table 6 Relationships between LDL particle size and various factors in the patients with NIDDM (diet) and IGT

\begin{tabular}{lc}
\hline & Correlation \\
\hline Total cholesterol & $-0.4348^{* *}$ \\
Triglyceride & $-0.5513^{* *}$ \\
HDL-C & $0.3704^{* *}$ \\
LDL-C & $-0.4047^{* *}$ \\
LDL-C/HDL-C & $-0.4680^{* *}$ \\
Apo A-I & 0.2366 \\
Apo B & $-0.4620^{* *}$ \\
Apo C-II & $-0.4025^{*}$ \\
Apo C-III & $-0.3835^{*}$ \\
BMI & $-0.3313^{*}$ \\
WHR & $-0.3923^{*}$ \\
VSR & -0.2827 \\
fasting IRI & $-0.2968^{*}$ \\
urinary CPR & -0.0468 \\
M-value & 0.3822 \\
\hline
\end{tabular}

$*: \mathrm{p}<0.05, * *: \mathrm{p}<0.01$

\section{3. 耐糖能異常者の LDL 亜分画と臨床的背景}

(Table 2)

いずれも男女別に small LDL 群と normal LDL 群で 比較した．年龄，糖尿病あるいは IGT 診断後の罹病年 数は両群で有意差がなかった. 血糖状態をみても, 空腹 時血糖 $(\mathrm{FPG}), \mathrm{HbA}_{1 \mathrm{C}}$ ともに有意差はなかった。

収縮期血圧，拡張期血圧はともに両群で差がみられな かった.
4. 耐糖能異常者の LDL 亜分画と血漿脂質, アポ蛋 白濃度 (Table 3 )

男性では, small LDL 群が normal LDL 群に比べ, TC, TG, LDL-C, アポ B,アポ C-II, アポ C-III 濃度お よび動脈硬化指数 (LDL-C/HDL-C) が有意に高值であ った．また，HDL-C は有意に低值であった，女性でも 男性と同様の傾向を示したが，HDL-C，アポC-II，アポ C-III には有意差が認められなかった。

\section{5. 耐糖能異常者の肥満とその特徵 (Table 4)}

男性では small LDL 群で BMI と VSR が有意に高值 であり，WHR も有意差はないが高值傾向 $(\mathrm{p}<0.1)$ であ った. 女性では small LDL 群で WHR が有意に高值で あり, BMI も高值傾向 $(\mathrm{p}<0.1)$ であった.

6. 耐糖能異常者の血漿 IRI, 尿中 CPR およびインス リン抵抗性 (Table 5)

男女とも空腹時 IRI は small LDL 群で有意に高值で あった. しかし，尿中 CPR では差がみられなかった. インスリン抵抗性では $\mathrm{M}$ 值に有意差を認めなかったが, small LDL 群で低值傾向を示した. また, 当教室の健常 者の平均值は男性 (年齢 $30.3 \pm 4.8$ 歳) では $7.11 \pm 1.38$ $\mathrm{mg} / \mathrm{min} / \mathrm{kg}$ ，女性 $(26.7 \pm 3.8$ 歳) では $7.90 \pm 1.57 \mathrm{mg} / \mathrm{min} /$ $\mathrm{kg}$ であり，これらと比較すると small LDL 群で有意に 低下していた。

\section{7. 耐糖能異常者の LDL 粒子径と各因子との相関}

(Table 6)

耐糖能異常者の全例で LDL 粒子径と各因子との関係 
をみると，粒子径と TC, TG, LDL-C とはいずれも有意 の負の相関，HDL-C とは正の相関を示した。また，ア ポ蛋白ではアポ B, C-II, C-III は負の相関を示した. 肥 満関係では LDL 粒子径と BMI, WHR が有意の負の相 関を示し, また, 空腹時 IRI も有意の負の相関を示し た.

\section{IV. 考察}

Austin と Krauss 注度勾配電気泳動法で LDL 亜分 画を pattern A, B に分類し，このうち pattern B は粒子 径が小さく高比重 (small, dense LDL) であり, 優性遺伝 の形式を示すことを報告した ${ }^{16)}$. その後, 本 LDL 亜分 画が虚血性心疾患発症の危険因子であること，高 TG 血 症, 低 HDL-C 血症, 高アポ B 血症などのリポ蛋白異 常を伴うこと，その発現は年齢に修飾されることなどを 明らかにしている ${ }^{17,18)}$ 。また，家族性複合型高脂血症 (FCHL) においては LDL が小粒子であることが報告さ れており ${ }^{20)}$ ，その本態の一部が pattern B と重なってい ると考えられる.この small, dense LDL は LDL 中の 一個のアポBに対して, コレステロールエステルの含有 量が少ないため, 粒子径が小さくかつ密度が高くなって いると推定されている16,21).

われわれも密度勾配電気泳動法で LDL 亜分画を検討 し, small LDL が脳梗塞患者で高頻度にみられ，本疾患 発症の危険因子の一つである可能性を示した ${ }^{15)}$.また, NIDDM においても small LDL が約 40\% と高頻度に みられ，糖尿病における血管障害の危険因子になりうる ことも推定した7). その際, small LDL をもつものは高 TG 血症, 低 HDL 血症打よび肥満傾向であり, DeFronzo のインスリン抵抗性症候群 ${ }^{3)}$ と類似することか ら，今回，外因性インズリンや $\mathrm{SU}$ 剤を使用していない 耐糖能異常者で, 本 LDL とリポ蛋白, 肥満, インスリ ンとの関係を検討した。

超遠心法で分離した LDL を密度勾配電気泳動後, 蛋 白染色する方法は再現性よく LDL 亜分画を同定でき, その主ピークがほぼ $25.5 \mathrm{~nm}$ 以下の小粒子径の場合, 非 対称的なスロープ状のパターンを示す (pattern B) ${ }^{17)}$. ᄂ かし，超遠心法を用いると多数検体の処理が困難であり， 今回は，血漿をそのまま泳動し脂肪染色する方法を用い た．本方法は簡便となるが，パターンを参考に LDL 亜 分画を分類することは困難であり，主ピークの粒子径の みで LDLを分類した. このためまず, 多数の健常者で検 討したところ， $25.7 \mathrm{~nm}$ に境界がみられ，ほとんどの例 がそれ以上であり，それ未満を small LDL とみなした。 この基準によると健常者の small LDL の頻度は約 4.1\% であり, Austin らの報告した健常者の pattern B の頻度
$25 \%$ 17) とかなり差がある，この違いは，人種の差か，食 事などの環境因子の差かは分からない。この LDL の主 ピークの年齢的な分布をみると，35 歳以下では small LDL はみられなかったが，それ以上では年齢による明， らかな変化はなかった。 また，男性が女性より小粒子の ところへ多く分布していた. Austin らも small, dense LDL は男性では 20 歳以上, 女性では閉経後に発現して くることや，女性の粒子径がより大きいことを述べてい $ろ^{18)}$.

今回の耐糖能異常者で small LDL の頻度を見ると $43.6 \%$ で, 年齢, 性, BMI を一致させた健常対照者 $5.5 \%$ に比べ明らかに高頻度であった。また，耐糖能異 常者で高脂血症合併例では特に高率に small LDL を認 めた。虚血性心疾患合併例 (7 例) では男性 2 例のみに認 め, small LDL 群と normal LDL 群で統計学的に差は なかった。これは対象の平均年齢が虚血性心疾患をきた すには低く，本疾患の合併例が少ないこともあり，今後 の検討が必要である.リポ蛋白に関しては, small LDL 群で TC, TG, LDL-C, 血漿アポ B 濃度が normal LDL 群に比し有意に高值，HDL-C が低值を示したが，これ らの変化は従来の報告7,15 17,22) とほぼ同様である.

高 TG 血症になると LDL 粒子径が小さくなることが 報告されている ${ }^{8,23)}$. 今回の症例でも TG と $\mathrm{LDL}$ 粒子 径の間には強い負の相関がみられたが, TG が $150 \mathrm{mg} / \mathrm{d} l$ 未満に限ってみても small LDL を示すものがやはり高 率にみられた. small LDL と TG 值とは密接な関係が あるが, 一時的な血中の TG 濃度が直接, 粒子径を変化 させているのではないと考えられる。すなわち， small LDL は，アポ B の上昇などからアポ B 含有粒子の数が 増加しており，VLDL の合成充進が基本にあると考え られる。

肥満は脂肪の分布状態によって, 男性型肥満 (上半身 型肥満, 中心性肥満あるいは内臟肥満）と女性型肥満 (下半身型肥満あるいは末梢性肥満) に分けられている が24), 最近，この肥満型が脂質代謝やインスリン感受性 と深く関係していることで注目されている11,12,25,26)。す なわち, 内臟脂肪は皮下脂肪に比しインスリン抵抗性が 強く，耐糖能異常，脂質代謝異常をきたしやすい．また， 内藏肥満は虚血性心疾患の合併が多いことも報告されて いる ${ }^{10)}$. 今回の small LDL と肥満型との関係をみた結 果, small LDL を有するものは BMI, WHR が高值を示 した. WHR は内臟脂肪の蓄積の一つの指標である. ま た，CT で直接脂肪分布をみた VSR は男性において有 意に増加していた。すなわち, small LDL 群は内臟肥満 が多いことを示している.

small LDL 群と normal LDL 群とで FPG, $\mathrm{HbA}_{1 \mathrm{C}}$ に 
差はなく，血糖の LDL 粒子径への影響はないと考えら れる.しかし, small LDL 群は空腹時 IRI の上昇㧍よ びインスリン抵抗性を認めた. NIDDM の初期の耐糖 能異常はインスリン感受性の低下に 起因する27) 場合が 多いとされ, 膵 $\beta$ 細胞が正常に機能しているうちは代償 的に高インスリン血症をきたすと考えられている．また， 糖尿病の高インスリン血症は主としてプロインスリンの 分泌増加といわれている. 今回の small LDL 群ではイ ンスリン抵抗性が強くプロインスリンの分泌が増加して いることが示唆される. 尿中 CPR でみると差がみられ なかったが，これはインスリンと CPR のクリアランス の相違 ${ }^{28)}$ や軽微な腎尿細管機能低下の合併が関与して いるかもしれない.

インスリン抵抗性のメカニズムにはインスリン受容体 レベルとインスリン受容体以降の細胞内代謝レベルでの 障害が考えられている.この抵抗性の因子に遺伝が考え られている ${ }^{3)}$ が, 肥満から 2 次的に生じることも知られ ており, 肥満者の肥大した脂肪細胞ではインスリン受容 体の数が減少すること ${ }^{29)}$ や細胞膜のグルコース 輸送担 体自体に活性の変化が生じていること到) などが報告さ れている.

small LDL の成因の一つとして VLDL の合成充進が 推定されるが，この合成六進はインスリン感受性の低下 あるいは肥満によるものかもしれない。すなわち,イン スリンは脂肪組織の脂肪分解を抑制するが, 肥満者の脂 肪組織はインスリンの作用以上に分解立進に傾きやす く ${ }^{31)}$, 肝への脂肪酸を増加させ VLDL 合成を促進させ る. 特に, 内臓脂肪はインスリンの抑制効果が少なく, 分解六進し門脈の脂肪酸を増加させることが報告されて いる32)。また，高インスリン血症は肝自体にも働き VLDL の合成を充進させる. 肥満も環境因子のみならず 遺伝的にも規定され, インスリン感受性低下の遺伝と相 互に関与している可能性がある. 一方, small LDL の発 現は遺伝的に支配されている ${ }^{16,19)}$ が，これも上記の遺 伝と関係しているかもしれない.

近年, 高血圧と高インスリン血症との関連が注目され， 上記インスリン抵抗性症候群でも高血圧の合併が重要な 項目となっている. 高インスリン血症が高血圧をもたら す理由はインスリンの腎尿細管の $\mathrm{Na}$ 再吸収促進や, 組 織細胞における $\mathrm{Na}-\mathrm{H}$ 交換ポンプ促進 ${ }^{33)}$, また, アドレ ナリン充進作用 ${ }^{34)}$ などが推定されている. 以前より糖 㽷病患者では高血圧合併率が高いことが知られているが, その頻度に人種差が存在することも指摘されている. 白 人では高血圧と高インスリン血症が相関する報告がある が35), 黒人や Pima Indian では相関しないとする報告 ${ }^{36)}$ がある.また, リポ蛋白異常と高血圧が合併する familial dyslipidemic hypertension (FDH) $\left.{ }^{37}\right)$ という症候群が報告 され，これには small LDLを呈することも述べられて いる. しかし, 今回の結果では small LDL 群と normal LDL 群で血圧の差はなかった. small LDL を呈する一 群はインスリン抵抗性症候群と本質的には同じであって も, 本邦人では肥満やインスリン抵抗性の程度が軽く, 血圧に関しては若干異なった外見を呈している可能性が ある。

リポ蛋白異常, 内臟肥満, インスリン抵抗性はそれぞ れ遺伝的および環境的多因子が複雑に絡み合って現れて いる. そして, これら遺伝的素因が clustering し, 症候 群として発現してくるものが, 動脈硬化性疾患発症者の 相当部分を占めている可能性がある. small LDL もこれ らのなかの一因子であり, また, これらの症候群をとら える一つの遺伝的表現形のマーカーとなりらるかもしれ ない. 今後, 本病態を解明していく上で, 各危険因子の 遺伝的解析や相互関係をさらに検討する必要がある.

\section{V. 結 論}

密度勾配ポリアクリルアミドゲル電気泳動を用い, 耐 糖能異常者55例 (食事療法のみの NIDDM および IGT) の LDL 粒子径を測定し, これと血墏りポ蛋白, 肥満, インスリン抵抗性を比較検討した.

1. 健常人 221 名の検討から, LDL の主なるピーク 径が $25.7 \mathrm{~nm}$ 末満を small LDL, 以上を normal LDL と分類した. 耐糖能異常者の群では small LDL を示す ものが $43.6 \%$ であり, 対照者の $5.5 \%$ に比べ有意に高 頻度であった。

2. 耐糖能異常者のなかで, small LDL 群は normal LDL 群に比し高 TC, 高 TG, 低 HDL-C, 高 apo B 血 症を示した. また, small LDL 群で BMI, WHR の増 加, 男性では VSR の増加を認め, 内藏肥満の傾向がみ られた。 さらに, 空腹時 IRI の高值とインスリン感受性 の低下がみられた。

3. 耐糖能異常者に扔ける small LDL の出現は, 高 TG, 低 HDL-C 血症, 肥満, 特に内藏肥満, インスリ ン抵抗性と関係していると考えられた。

\section{文献}

1) Reaven, G. M.: Role of insulin resistance in human disease. Diabetes, 37: 1595-1607 (1988).

2) Kaplan, N. M.: The deadly quartet. Upper-body obesity, glucose intolerance, hypertriglyceridemia, and hypertension. Arch. Intern. Med., 149: 15141520 (1989).

3) DeFronzo, R. A. and Ferrannini, E.: Insulin resistance. A multifaceted syndrome responsible for NIDDM, obesity, hypertension, dyslipidemia, and 
atherosclerotic cardiovascular disease. Diabetes Care, 14: 173-194 (1991).

4) Adams, G. H. and Schumaker, V. N.: Polydispersity of human low-density lipoproteins. Ann. N.Y. Acad. Sci., 164: 130-146 (1969).

5) Krauss, R. M. and Burke, D. J.: Identification of multiple subclasses of plasma low density lipoproteins in normal humans. J. Lipid Res., 23: 97-104 (1982).

6) Fisher, W. R.: Heterogeneity of plasma low density lipoproteins manifestations of the physiologic phenomenon in man. Metabolism, 32: 283-291 (1983).

7) 大黒隆司，末廣 正，大野文俊：NIDDM 患者に抒 ける LDL 垔分画 pattern B(small, dense LDL)の検 討. 動脈硬化, 19: 161-169 (1991).

8) Eisenberg, S., Gavish, D., Oschry, Y., Fainaru, M. and Deckelbaum, R. J.: Abnormalities in very low, low, and high density lipoproteins in hypertriglyceridemia. Reversal toward normal with bezafibrate treatment. J. Clin. Invest., 74: 470-482 (1984).

9) Williams, P. T., Krauss, R. M., Nichols, A. V., Vranizan, K. M. and Wood, P. D. S.: Identifying the predominant peak diameter of high-density and lowdensity lipoproteins by electrophoresis. J. Lipid Res., 31: 1131-1139 (1990).

10) Larsson, B., Svärdsudd, K., Welin, L., Wilhelmsen, L., Björntorp, P. and Tibblin, G. : Abdominal adipose tissue distribution, obesity, and risk of cardiovascular disease and death: 13 year follow up of participants in the study of men born in 1913. Brit. Med. J., 288: 1401-1404 (1984).

11) Tokunaga, K., Matsuzawa, Y., Ishikawa, K. and Tarui, S.: A novel technique for the determination of body fat by computed tomography. I. J. Obesity, 7: 437-445 (1983).

12) Fujioka, S., Matsuzawa, Y., Tokunaga, K. and Tarui, S.: Contribution of intra-abdominal fat accumulation to the impairment of glucose and lipid metabolism in human obesity. Metabolism, 36: 5459 (1987).

13) DeFronzo, R. A., Tobin, J. D. and Andres, R.: Glucose clamp technique: A method for quantifying insulin secretion and resistance. Am. J. Physiol., 237: E214-223 (1979).

14）川田益意, 末廣 正, 高松和永, 安岡伸和, 吉田健 三，岸野和貴子，久武邦彦，宇賀茂敏，山野利尚， 大野文俊：デキストラン硫酸沈搌法による $\mathrm{HDL}_{2-}$, $\mathrm{HDL}_{3}$-Cholesterol 測定法の検討と臨床成績. 動脈硬 化, 12: 887-894 (1984).

15）岡村浩司, 川田益意, 末廣 正, 大野文俊：脳梗塞 患者に括ける small, dense low density lipoprotein の 検討. 動脈硬化, 19: 1079-1088 (1991).

16) Austin, M. A. and Krauss, R. M.: Genetic control of low-density-lipoprotein subclasses. Lancet, 13: 592595 (1986).

17) Austin, M. A., Breslow, J. L., Hennekens, C. H., Buring, J. E., Willett, W. C. and Krauss, R. M.: Low-density lipoprotein subclass patterns and risk of myocardial infarction. J.A.M.A., 260: 1917-1921 (1988).
18) Austin, M. A., King, M.-C., Vranizan, K. M., Newman, B. and Krauss, R. M.: Inheritance of lowdensity lipoprotein subclass patterns: Results of complex segregation analysis. Am. J. Hum. Genet., 43: 838-846 (1988).

19) Austin, M. A., King, M.-C., Vranizan, K. M. and Krauss, R. M.: Atherogenic lipoprotein phenotype. A proposed genetic marker for coronary heart disease risk. Circulation, 82: 495-506 (1990).

20) Austin, M. A., Brunzell, J. D., Fitch, W. L. and Krauss, R. M.: Inheritance of low density lipoprotein subclass patterns in familial combined hyperlipidemia. Arteriosclerosis, 10: 520-530 (1990).

21) Teng, B., Thompson, G. R., Sniderman, A. D., Forte, T. M., Krauss, R. M. and Kwiterovich, P. O. Jr.: Composition and distribution of low density lipoprotein fractions in hyperapobetalipoproteinemia, normolipidemia, and familial hypercholesterolemia. Proc. Natl. Acad. Sci. U.S.A., 80: 6662-6666 (1983).

22) McNamara, J. R., Campos, H., Ordovas, J. M., Peterson, J., Wilson, P. W. F. and Schaefer, E. J.: Effect of gender, age, and lipid status on low density lipoprotein subfraction distribution. Results from the Framingham offspring study. Arteriosclerosis, 7: 483-490 (1987).

23) Deckelbaum, R. J., Granot, E., Oschry, Y., Rose, L. and Eisenberg, S.: Plasma triglyceride determines structure-composition in low and high density lipoproteins. Arteriosclerosis, 4: 225-231 (1984).

24) Vague, J.: The degree of masculine differentiation of obesities: A factor determining predisposition to diabetes, atherosclerosis, gout, and uric calculous disease. Am. J. Clin. Nutr., 4: 20-34 (1956).

25) Evans, D. J., Hoffmann, R. G., Kalkhoff, R. K. and Kissebah, A. H. : Relationship of body fat topography to insulin sensitivity and metabolic profiles in premenopausal women. Metabolism, 33: 68-75 (1984).

26) Kissebah, A. H. and Peiris, A. N.: Biology of regional body fat distribution: Relationship to noninsulin-dependent diabetes mellitus. Diab. Metab. Rev., 5: 83-109 (1989).

27) Reaven, G. M. and Miller, R. G.: An attempt to define the nature of chemical diabetes using a multidimensional analysis. Diabetologia, 16: 17-24(1979).

28) Yoshioka, N., Kuzuya, T., Matsuda, A. and Iwamoto, Y.: Effects of dietary treatment on serum insulin and proinsulin response in newly diagnosed NIDDM. Diabetes, 38: 262-266 (1989).

29) Olefsky, J. M.: Decreased insulin binding to adipocytes and circulating monocytes from obese subjects. J. Clin. Invest., 57: 1165-1172 (1976).

30) Karnieli, E., Barzilai, A., Rafaeloff, R. and Armoni, M.: Distribution of glucose transporters in membrane fractions isolated from human adipose cells. Relation to cell size. J. Clin. Invest., 78: 1051-1055 (1986).

31) Roncari, D. A. K., Kindler, S. and Hollenberg, C. H.: Excessive proliferation in culture of reverted adipocytes from massively obese persons. Metabolism, 35: 1-4 (1986). 
32) Svedberg, J., Björntorp, P., Smith, U. and Lönnroth, P.: Free-fatty acid inhibition of insulin binding, degradation, and action in isolated rat hepatocytes. Diabetes, 39: 570-574 (1990).

33) DeFronzo, R. A.: The effect of insulin on renal sodium metabolism. A review with clinical implications. Diabetologia, 21: 165-171 (1981).

34) Christlieb, A. R., Janka, H.-U., Kraus, B., |Gleason, R. E., Icasas-Cabral, E. A., Aiello, L. M., Cabral, B. V. and Solano, A.: Vascular reactivity to angiotensin II and to norepinephrine in diabetic subjects. Diabetes, 25: 268-274 (1976).

35) Saad, M. F., Lillioja, S., Nyomba, B. L., Castillo, C., Ferraro, R., DeGregorio, M., Ravussin, E., Knowler, W. C., Bennett, P. H., Howard, B. V. and Bogardus,
C.: Racial differences in the relation between blood pressure and insulin resistance. N. Engl. J. Med., 324: 733-739 (1991).

36) Saad, M. F., Knowler, W. C., Pettitt, D. J., Nelson, R. G., Mott, D. M. and Bennett, P. H.: Insulin and hypertension. Relationship to obesity and glucose intolerance in Pima Indians. Diabetes, 39: 1430-1435 (1990).

37) Williams, R. R., Hunt, S. C., Hopkins, P. N., Stults, B. M., Wu, L. L., Hasstedt, S. J., Barlow, G. K., Stephenson, S. H., Lalouel, J.-M. and Kuida, H.: Familial dyslipidemic hypertension. Evidence from 58 Utah families for a syndrome present in approximately $12 \%$ of patients with essential hypertension. J.A.M.A., 259: 3579-3586 (1988).

\title{
Summary
}

\section{The Relationship between Small, Low-Density Lipoprotein Particles and Plasma Lipids, Obesity, and Insulin Sensitivity in Patients with Glucose Intolerance}

\author{
Ryota Sumiyoshi, Tadashi Suehiro, Kozo Hashimoto and Fumitoshi OhNo
}

\author{
Second Department of Internal Medicine, Kochi Medical School
}

We examined plasma LDL particle size in 55 patients (35 males, 20 females) with NIDDM (diet alone) or IGT (WHO), and investigated the relationship between LDL particle size and plasma lipids, obesity, and peripheral insulin sensitivity. 55 healthy adults of similar sex, age, and body mass index (BMI) were used as a control group. Peak LDL particle size was measured by nondenaturing $2 \%$ to $16 \%$ polyacrylamide gradient gel electrophoresis and oil red $\mathrm{O}$ staining. In this study any LDL particle size less than $25.7 \mathrm{~nm}$ was defined as "small LDL", and anything over $25.7 \mathrm{~nm}$ was defined as "normal LDL". The mean peak LDL particle sizes of the patients and controls were $25.81 \pm 0.79$ and $26.66 \pm$ $0.75 \mathrm{~nm}$, respectively. The frequency of small LDL in the patients was significantly higher than that in the control group ( $43.6 \%$ vs. $5.5 \%$ ). In the patients, there was no difference in the blood pressure in the small LDL group and the normal LDL group. The total cholesterol, triglyceride, and apo B levels in both male and female patients were significantly higher in the small LDL group than in the normal LDL group. By contrast, the HDL-C level in male patients was significantly lower in the small LDL group. The BMI and the ratio of waist-to-hip circumference in both male and female patients tended to be higher in the small LDL groups than those in the normal LDL groups (female: $27.1 \pm 4.2$ vs. $22.4 \pm 5.4,1.004 \pm 0.041$ vs. $0.911 \pm 0.066$; male: $26.1 \pm 2.5$ vs. $23.7 \pm 3.6,0.956 \pm 0.036$ vs. $0.931 \pm$ 0.043). Moreover the ratio of intra-abdominal visceral fat to subcutaneous fat, which was measured using an abdominal CT scan, was higher in the small LDL group of male patients $(0.549 \pm 0.135$ vs. $0.382 \pm 0.069)$. The fasting IRI levels of both male and female patients were significantly higher in the small LDL groups than those in the normal LDL groups (female: $19.38 \pm 16.80$ vs. $9.17 \pm 4.84 \mu \mathrm{U} / \mathrm{ml}$; male: $12.45 \pm 7.67$ vs. $7.14 \pm 3.22 \mu \mathrm{U} / \mathrm{ml}$ ). A euglycemic insulin clamp study showed that the glucose disposable rate in the small LDL group was significantly lower than that in the healthy control group (female: $2.34 \pm 0.04$ vs. $7.90 \pm 1.57 \mathrm{mg} / \mathrm{min} / \mathrm{kg}$; male: $3.61 \pm 1.79$ vs. $7.11 \pm 1.38 \mathrm{mg} / \mathrm{min} / \mathrm{kg}$ ). These results suggest that glucose intolerance in the small LDL group is closely related to hypertriglyceridemia, low HDL-C, visceral obesity and peripheral insulin resistance.

Key words: small, low-density lipoprotein, obesity, insulin resistance, NIDDM, gradient gel electrophoresis. 